Check for updates

Cite this: Mater. Adv., 2020, 1,2831

Received 21st August 2020 Accepted 21st September 2020

DOI: $10.1039 / \mathrm{d} 0 \mathrm{ma} 00629 \mathrm{~g}$

rsc.li/materials-advances

\section{Development of an ultra-sensitive para-nitrophenol sensor using tri-metallic oxide $\mathrm{MoO}_{2} \cdot \mathrm{Fe}_{3} \mathrm{O}_{4} \cdot \mathrm{CuO}$ nanocomposites $\dagger$}

\author{
Md Abdus Subhan, (D) *a Pallab Chandra Saha, (D) ${ }^{a}$ Jahir Ahmed, ${ }^{a}$ \\ Abdullah M. Asiri, (D) ${ }^{b}$ Mohammad Al-Mamun (D) ${ }^{c}$ and Mohammed M. Rahman (D)*b
}

A tri-metal oxide, $\mathrm{MoO}_{2} \cdot \mathrm{Fe}_{3} \mathrm{O}_{4} \cdot \mathrm{CuO}$ (TMO), was synthesized by the co-precipitation method and characterized by XRD, SEM-EDS, and FTIR. The average particle size of the nanocomposite was found to be $34.85 \mathrm{~nm}$. The zeta potential and hydrodynamic size of the $\mathrm{MoO}_{2} \cdot \mathrm{Fe}_{3} \mathrm{O}_{4} \cdot \mathrm{CuO}$ nanocomposite were studied in acidic and basic $\mathrm{pH}$ respectively. A glassy carbon electrode (GCE) was modified by $\mathrm{MoO}_{2} \cdot \mathrm{Fe}_{3} \mathrm{O}_{4} \cdot \mathrm{CuO}$ to develop a chemical sensor for para-nitrophenol ( $p$-NP). A simple I-V method was employed for this study. Excellent sensitivity, an ultra-low detection limit, long-term stability, and reproducibility of the $\mathrm{MoO}_{2} \cdot \mathrm{Fe}_{3} \mathrm{O}_{4} \cdot \mathrm{CuO} / \mathrm{Nafion} / \mathrm{GCE}$ sensor were observed towards $p-\mathrm{NP}$. A linear calibration plot $\left(r^{2}\right.$ : 0.9995) was obtained for $1.0 \mathrm{pM}$ to $0.01 \mathrm{mM}$ aqueous $p$-NP solution, with a sensitivity value of $5.2430 \mu \mathrm{A} \mu \mathrm{M}^{-1} \mathrm{~cm}^{-2}$ and remarkably low detection limit (LOD) of $0.2 \mathrm{pM}$.

\section{Introduction}

There have been a number of studies on advances of mixed metal oxide catalysts. ${ }^{1-3}$ The electronic and molecular structures of metal oxides have attracted special attention because of the presence of multiple oxidation states and variable nonconventional local coordination. They have simultaneous bulk and surface phases as well as different surface functionalities. Mixed metal oxides comprise the largest family of heterogeneous catalysts for numerous applications. Composite oxides are better in terms of their catalytic activity than constituent oxides. It is due to the increasing active acidic or basic sites as well as the increasing surface area on mixed metal oxides. ${ }^{4}$

Many industrially important processes have been explored with mixed metal oxide nanocomposites. ${ }^{5-7}$ Significant progress for technological development might be achieved by the use of those nano mixed metal oxides. $\mathrm{MoO}_{2}$ is a larger bandgap semiconductor $(3.85 \mathrm{eV})$ than $\mathrm{MoO}_{3}(2.90 \mathrm{eV})$. When

\footnotetext{
${ }^{a}$ Department of Chemistry, School of Physical Sciences, Shahjalal University of Science and Technology, Sylhet-3114, Bangladesh. E-mail: subhan-che@sust.edu; Tel: +8801716073270

${ }^{b}$ Center of Excellence for Advanced Materials Research (CEAMR) \& Department of Chemistry, Faculty of Science, King Abdulaziz University, P.O. Box 80203, Jeddah 21589, Saudi Arabia. E-mail: mmrahman@kau.edu.sa, mmrahmanh@gmail.com; Fax: +966-12-695-2292; Tel: +966-59-642-1830

${ }^{c}$ Centre for Clean Environment and Energy, Griffith School of Environment, Gold Coast Campus, Griffith University, QLD 4222, Australia

$\dagger$ Electronic supplementary information (ESI) available. See DOI: 10.1039/ d0ma00629g
}

crystallized, $\mathrm{MoO}_{2}$ showed spherical morphology whereas $\mathrm{MoO}_{3}$ forms hexagonal or rectangular plates, based on the synthesis conditions. ${ }^{8,9} \mathrm{MoO}_{2}$ has excellent applications in field emission devices, promising anode materials, and optical materials. ${ }^{9}$ Thermodynamically, the stability of the amorphous phases is lower than that of orthorhombic $\mathrm{MoO}_{3} \cdot{ }^{10}$ This oxide is normally found in the orthorhombic phase, which has many applications. This phase can be described as a layered structure formed by covalent double layers of $\mathrm{MoO}_{6}$ octahedra. There have been studies on the antimicrobial, antioxidant, and cytotoxic effects of molybdenum oxide nanoparticles. ${ }^{11}$

In nature, iron(III) oxide is found in the form of rust. Generally, iron oxides are widespread, widely used as they are inexpensive, and play an important role in many biological as well as geological processes. They are also extensively used by humans including iron ores in thermite, catalysts, durable pigments (coatings, paints, and colored concrete), and hemoglobin. The three most common forms of iron oxides in nature are magnetite $\left(\mathrm{Fe}_{3} \mathrm{O}_{4}\right)$, maghemite $\left(\gamma-\mathrm{Fe}_{2} \mathrm{O}_{3}\right)$, and hematite $\left(\alpha-\mathrm{Fe}_{2} \mathrm{O}_{3}\right)$. NPs composed of ferromagnetic materials and with size $<10-20 \mathrm{~nm}$ exhibit a unique form of magnetism, i.e., super para-magnetism.

Oxide-based nanomaterials such as $\mathrm{CuO}$ have been gaining interest in nanomaterials research. Semiconducting oxides such as $\mathrm{CuO}$ and $\mathrm{Cu}_{2} \mathrm{O}$ have distinguishing properties and are now widely used as transparent semiconducting oxide materials and chemical and biological sensors. This study was conducted to synthesize and characterize a tri-metal oxide from single metal oxides of interest, for exploring electrochemical 
sensor applications, because trimetallic oxide nanocomposites are promising systems for toxin sensors, photocatalytic applications and environmental safety, an efficient anti-bacterial agent against MDR bacteria, and industrial sterilization mediators. ${ }^{12-16}$

Phenolic compounds and their derivatives are extensively used in the production of pharmaceuticals, dyes, pesticides, etc., and are known as severe environmental toxins. ${ }^{17,18}$ They cause severe damage to organisms and plants. ${ }^{19}$ paraNitrophenol ( $p$-NP) is an ingredient of the parathioninsecticide, which is a reason for anxiety because of its severe effects. $p$-NP is considered as one of the major toxic pollutants by the US Environmental Protection Agency (EPA). ${ }^{20,21}$ As a result, for ecological security and food safety, there is an urgent need to produce an effective method for the detection and quantification of $p$-NP. Some traditional analytical methods have been reported for the detection of $p$-NP. ${ }^{22-25}$ The electrochemical method offers various potential advantages such as a fast response, cost-effectiveness, and simple operation steps with good sensitivity and selectivity for the detection of $p$-NP. Electrodes including gold and glassy carbon electrodes in the electrochemical analysis are known to show good performance. However, still there is a need for ultrasensitive detection for a very low concentration of $p$-NP in $\mathrm{pM}$ in water. Modification of electrodes with various nanostructured materials may offer such opportunities. ${ }^{26,27}$ Carbon-based nanomaterial containing electrodes such as carbon paste, carbon nanotube, and graphene electrodes are used extensively in the electrochemical determination of $p$-NP. ${ }^{28,29}$ Nanographene is an excellent electrode material for $p$-NP determination because of its excellent charge transport properties, large surface to volume ratio, high electrocatalytic activity, and thermal conductivity. ${ }^{30,31}$ There have been studies on the detection of $p$-NP using graphene/graphene oxide modified electrodes within the range of a few hundred nanomolar. ${ }^{32}$

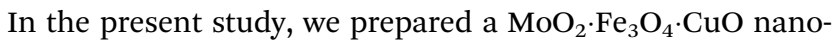
composite by the co-precipitation method for the electrochemical detection of $p$-NP at ambient conditions. The structural and morphological properties of $\mathrm{MoO}_{2} \cdot \mathrm{Fe}_{3} \mathrm{O}_{4} \cdot \mathrm{CuO}$ were studied by various techniques. After synthesis of $\mathrm{MoO}_{2} \cdot \mathrm{Fe}_{3} \mathrm{O}_{4} \cdot \mathrm{CuO}$, we coated the nanocomposite onto a GCE for the evaluation of the electrochemical performance for the detection of $p$-NP. ${ }^{33,34}$ Besides, we also compared the electrochemical response of the $\mathrm{MoO}_{2} \cdot \mathrm{Fe}_{3} \mathrm{O}_{4} \cdot \mathrm{CuO}$ nanocomposite with a bare GCE and $\mathrm{MoO}_{2} \cdot \mathrm{Fe}_{3} \mathrm{O}_{4} \cdot \mathrm{CuO} / \mathrm{GCE}$ for the detection of $p$-NP, which indicates that the $\mathrm{MoO}_{2} \cdot \mathrm{Fe}_{3} \mathrm{O}_{4} \cdot \mathrm{CuO}$ nanocomposite shows better performance.

\section{Experimental section}

\section{Materials and methods}

$\mathrm{MoCl}_{2}$ (Sigma Aldrich, Germany), $\mathrm{Fe}\left(\mathrm{NO}_{3}\right)_{3} \cdot 9 \mathrm{H}_{2} \mathrm{O}$ (MERCK, India), $\mathrm{CuCl}_{2} \cdot 3 \mathrm{H}_{2} \mathrm{O}(\mathrm{AR}, \mathrm{BDH}), \mathrm{Na}_{2} \mathrm{CO}_{3}(\mathrm{AR}, \mathrm{BDH}), \mathrm{NaOH}$ $(\mathrm{AR}, \mathrm{BDH})$, and $\mathrm{HCl}(\mathrm{AR}, \mathrm{BDH})(\mathrm{GPR}, \mathrm{BDH})$ were purchased and used without further purification. Disodium phosphate, monosodium phosphate, 2-aminophenol, 4-methoxyphenol,
p-NP, 3-chlorophenol, 2,4-dinitrophenol, bisphenol A, hydrazine, paracetamol, 4-nitrophenyl hydrazine, and 5\% ethanolic Nafion solution were also purchased from Sigma-Aldrich. All chemicals were of analytical grade and used without further purification. The identification of the crystal phase and evaluation of other structural information of the nanomaterials studied in this work was performed by X-ray diffraction (XRD, Bruker D8 Advance diffractometer, equipped with a graphite monochromator). The diffraction patterns were recorded within the $2 \theta$ angle range from $10^{\circ}$ to $80^{\circ}$ in the step scan mode at 0.05 steps and at a rate of $10 \mathrm{~s}$ per step. ${ }^{34}$ The surface morphology was studied using a Scanning Electron Microscope (SEM) with an Energy-Dispersive X-ray Spectrometer (EDS) (JSM-7100F) linked with an EDS mapping appliance. FTIR analysis of the samples was carried out using an FTIR spectrometer (Shimadzu, FTIR-8400S). The hydrodynamic size and zeta potential were measured using a Zetasizer Nanoseries (Nano-ZS90). I-V measurements of the fabricated $\mathrm{MoO}_{2}$. $\mathrm{Fe}_{3} \mathrm{O}_{4} \cdot \mathrm{CuO} / \mathrm{Nafion} / \mathrm{GCE}$ composites were conducted to detect $p$-nitrophenol using a Keithley electrometer (6517A, USA) at ambient conditions as reported recently. ${ }^{34}$

\section{Preparation of the $\mathrm{TMO} \mathrm{MoO}_{2} \cdot \mathrm{Fe}_{3} \mathrm{O}_{4} \cdot \mathrm{CuO}$ nanocomposite}

The $\mathrm{MoO}_{2} \cdot \mathrm{Fe}_{3} \mathrm{O}_{4} \cdot \mathrm{CuO}$ nanocomposite was synthesized by a reliable and low-cost co-precipitation method. This synthetic process was started by preparing $0.25 \mathrm{M}$ solutions of $\mathrm{MoCl}_{2}$, $\mathrm{Fe}\left(\mathrm{NO}_{3}\right)_{3} \cdot 9 \mathrm{H}_{2} \mathrm{O}$, and $\mathrm{CuCl}_{2} \cdot 3 \mathrm{H}_{2} \mathrm{O}$, which act as sources of molybdenum, iron, and copper, respectively. All of them were mixed in a beaker in the same volume ratio $(50 \mathrm{~mL})$ with constant stirring for 15 minutes. To the above mixture $0.5 \mathrm{M}$ $\mathrm{Na}_{2} \mathrm{CO}_{3}$ was added dropwise until completion of the reaction at $45{ }^{\circ} \mathrm{C}$. The resultant mixture was stirred constantly for another 1 hour at $45{ }^{\circ} \mathrm{C}$. When the reaction was completed, the white precipitate was separated from the solution by centrifugation, then washed several times with deionized water and finally dried at $120{ }^{\circ} \mathrm{C}$ in an oven for 2 hours. The white sample was calcined in an electric muffle furnace (Gallenkamp, Korea) at $600{ }^{\circ} \mathrm{C} .{ }^{35}$ The calcination transformed the metal carbonates into metal oxides. ${ }^{36}$ The reactions can be summarized as below:

$$
\begin{gathered}
\left(\mathrm{Mo}^{2+}+\mathrm{Cl}^{-}\right)+\left(\mathrm{Na}^{+}+\mathrm{CO}_{3}{ }^{2-}\right)+\mathrm{HOH} \rightarrow \mathrm{MoCO}_{3} \cdot(\mathrm{OH})_{2} \\
+\mathrm{CO}_{2}+\left(\mathrm{Na}^{+}+\mathrm{Cl}^{-}\right) \\
2 \mathrm{Fe}\left(\mathrm{NO}_{3}\right)_{3} \cdot 9 \mathrm{H}_{2} \mathrm{O}+3\left(\mathrm{Na}^{+}+\mathrm{CO}_{3}^{2-}\right)+\mathrm{HOH} \rightarrow \mathrm{Fe}_{2}\left(\mathrm{CO}_{3}\right)_{2} \cdot \\
(\mathrm{OH})_{2}+\left(\mathrm{Na}^{+}+\mathrm{NO}_{3}^{-}\right) \\
\left(\mathrm{Cu}^{2+}+\mathrm{Cl}^{-}\right)+\left(\mathrm{Na}^{+}+\mathrm{CO}_{3}^{2-}\right)+\mathrm{HOH} \rightarrow \mathrm{CuCO}_{3} \cdot(\mathrm{OH})_{2} \\
+\left(\mathrm{Na}^{+}+\mathrm{Cl}^{-}\right) \\
3 \mathrm{MoCO}_{3} \cdot(\mathrm{OH})_{2} \rightarrow 3 \mathrm{MoO}_{2}+3 \mathrm{CO}_{2} \\
3 \mathrm{Fe}_{2}\left(\mathrm{CO}_{3}\right)_{2} \cdot(\mathrm{OH})_{2} \rightarrow 2 \mathrm{Fe}_{3} \mathrm{O}_{4}+6 \mathrm{CO}_{2} \\
\mathrm{CuCO}_{3} \cdot(\mathrm{OH})_{2} \rightarrow \mathrm{CuO}^{2}+\mathrm{CO}_{2} \\
\mathrm{MoO}_{2}+\mathrm{Fe}_{3} \mathrm{O}_{4}+\mathrm{CuO} \rightarrow \mathrm{MoO}_{2} \cdot \mathrm{Fe}_{3} \mathrm{O}_{4} \cdot \mathrm{CuO}
\end{gathered}
$$




\section{Modification of a GCE with the TMO nanocomposite}

The synthesized $\mathrm{MoO}_{2} \cdot \mathrm{Fe}_{3} \mathrm{O}_{4} \cdot \mathrm{CuO}$ was used to fabricate a GCE by using a $5 \%$ ethanolic solution of Nafion to get an approximately $0.4 \mathrm{~mm}$ thick film. It was then heated in an oven at $45 .{ }^{\circ} \mathrm{C}$ for 2 hours to get the dry film on the GC electrode. In an electro-chemical cell, the $\mathrm{MoO}_{2} \cdot \mathrm{Fe}_{3} \mathrm{O}_{4} \cdot \mathrm{CuO}$ nanocomposite fabricated GCE was used as a working electrode (WE), a platinum wire was the counter electrode (CE), and aqueous p-NP in 0.1 M phosphate buffer solution (PBS; pH 7.0) was used as the supporting electrolyte. To utilize the target chemical, aqueous $p$-NP $(1.0 \mathrm{mM})$ was systematically diluted to various concentrations (1.0 $\mathrm{mM}$ to $1.0 \mathrm{pM})$ using deionized water. All the $I-V$ measurements were performed in $5.0 \mathrm{~mL}$ of PBS $(\mathrm{pH}=7.0)$. From the slope of the calibration plot, the sensitivity of the proposed $p$-NP sensor was calculated by considering the active surface area of the GCE. By using an electrometer (Keithley, 6517A electrometer, USA) the $I-V$ method was applied to aqueous $p$-NP taking $\mathrm{MoO}_{2} \cdot \mathrm{Fe}_{3} \mathrm{O}_{4} \cdot \mathrm{CuO} / \mathrm{GCE}$ as a working electrode.

\section{Results and discussion}

\section{Structural characterization of the $\mathrm{MoO}_{2} \cdot \mathrm{Fe}_{3} \mathrm{O}_{4} \cdot \mathrm{CuO}$ nanocomposite}

The XRD pattern of $\mathrm{MoO}_{2} \cdot \mathrm{Fe}_{3} \mathrm{O}_{4} \cdot \mathrm{CuO}$ is as depicted in Fig. 1 . There are three oxides $\mathrm{MoO}_{2}, \mathrm{Fe}_{3} \mathrm{O}_{4}$ and $\mathrm{CuO}$ in the synthesized nanocomposite. One of them is monoclinic, $C 2 / c(15)$, tenorite $(\mathrm{CuO})$, which shows peaks at $2 \theta=32.505^{\circ}, 35.498^{\circ}, 38.698^{\circ}$, $46.153^{\circ}, 48.702^{\circ}, 51.346^{\circ}, 58.144^{\circ}, 61.548^{\circ}, 65.659^{\circ}, 66.152^{\circ}$, $67.954^{\circ}$, and $72.208^{\circ}$ (JCPDS\#72-0629) with lattice constants $a$, $b, c$ and $(\alpha \beta \gamma)$ of $4.6837,3.4226,5.1288$ and $(90.0 \times 99.54 \times$ $90.0)$, density $(\rho)=6.515$ and volume $=81.1$. Another one is magnetite $\left(\mathrm{Fe}_{3} \mathrm{O}_{4}\right)$ (cubic, $F d \overline{3} m(227)$ ) having $2 \theta=18.326^{\circ}$, $35.498^{\circ}, 37.139^{\circ}, 43.01^{\circ}, 57.044^{\circ}, 66.152^{\circ}, 71.101^{\circ}, 74.243^{\circ}$, and $79.086^{\circ}$ (JCPDS\#88-0315). Its lattice constants $a, b, c$ and $(\alpha \beta \gamma)$ are $8.375,8.375,8.375$ and $(90.0 \times 90.0 \times 90.0)$ with density $(\rho)=5.235$, and volume 587.4 . The third one is also monoclinic, $P 21 / c(14), \mathrm{MoO}_{2}$, with $2 \theta$ peaks at $18.326^{\circ}, 37.139^{\circ}$, $41.303^{\circ}, 41.913^{\circ}, 49.467^{\circ}, 59.834^{\circ}, 63.999^{\circ}, 66.152^{\circ}, 70.306^{\circ}$, $72.208^{\circ}$, and $79.086^{\circ}$ (JCPDS\#86-0135). Its lattice constants $a$, $b, c$ and $(\alpha \beta \gamma)$ are 5.609, 4.86, 5.628 and $(90.0 \times 120.94 \times 90.0)$ respectively. The particle size of the nanocomposite was estimated from XRD data using Scherrer's formula $\tau=K \lambda /(\beta \cos \theta)$. Here $\tau$ is the mean size, $K$ is a dimensionless shape factor with a value $0.94, \lambda$ is the X-ray wavelength $(0.1506 \mathrm{~nm}), \beta$ is the line broadening at half the maximum intensity (FWHM) and $\theta$ is the Bragg angle. The average particle size of the $\mathrm{MoO}_{2} \cdot \mathrm{Fe}_{3} \mathrm{O}_{4} \cdot \mathrm{CuO}$ nanocomposite was found to be $34.85 \mathrm{~nm}$.

\section{Morphological and elemental analysis of the $\mathrm{MoO}_{2} \cdot \mathrm{Fe}_{3} \mathrm{O}_{4} \cdot \mathrm{CuO}$ nanocomposite}

An SEM study (as in Fig. 2a and b) was performed to reveal a clear image of the surface morphology and particles of synthesized nanocomposite $\mathrm{MoO}_{2} \cdot \mathrm{Fe}_{3} \mathrm{O}_{4} \cdot \mathrm{CuO}$. Fig. 2(a) shows that the nanocomposite formed in mixed cubic, rectangular and spherical morphologies. EDS mapping was carried out to map the elemental compositions of the nanocomposite. As is seen from the EDS data (Fig. S1 and Table S1, ESI $\dagger$ ) the nanocomposites consist of $\mathrm{Mo}, \mathrm{Fe}, \mathrm{Cu}$, and $\mathrm{O}$ with an atomic percentage of $2.5 \%$, $30.85 \%, 14.8 \%$, and $51.85 \%$ respectively. The EDS mapping also indicated that the elements were distributed throughout the matrix (Fig. S2, ESI $\dagger$ ).

\section{FTIR study of the $\mathrm{MoO}_{2} \cdot \mathrm{Fe}_{3} \mathrm{O}_{4} \cdot \mathrm{CuO}$ nanocomposite}

Fig. S3 (ESI $\dagger$ ) shows the FTIR spectrum of the $\mathrm{MoO}_{2} \cdot \mathrm{Fe}_{3} \mathrm{O}_{4} \cdot \mathrm{CuO}$ nanocomposite in 400-4000 $\mathrm{cm}^{-1}$. The band centred at $3433 \mathrm{~cm}^{-1}$ is assigned to the stretching mode of atmospheric $\mathrm{H}_{2} \mathrm{O}^{37}$ The FTIR spectrum of the sample calcined at $600{ }^{\circ} \mathrm{C}$ showed the stretching mode of $\mathrm{Mo}=\mathrm{O}$ at $966 \mathrm{~cm}^{-1}$ and $\mathrm{Mo}-\mathrm{O}$ at $823 \mathrm{~cm}^{-1}$, and $775 \mathrm{~cm}^{-1}$. The IR peak at $717 \mathrm{~cm}^{-1}$ is attributed to the Mo-O-Mo stretching vibrations. ${ }^{38}$ The sample exhibited an intense peak at $599 \mathrm{~cm}^{-1}$ due to the stretching vibration mode associated with the iron-oxygen band ( $\mathrm{Fe}-\mathrm{O}$ bonds in the crystalline lattice of $\left.\mathrm{Fe}_{3} \mathrm{O}_{4}\right) \cdot{ }^{39}$ The peak at $433 \mathrm{~cm}^{-1}$ is attributed to the

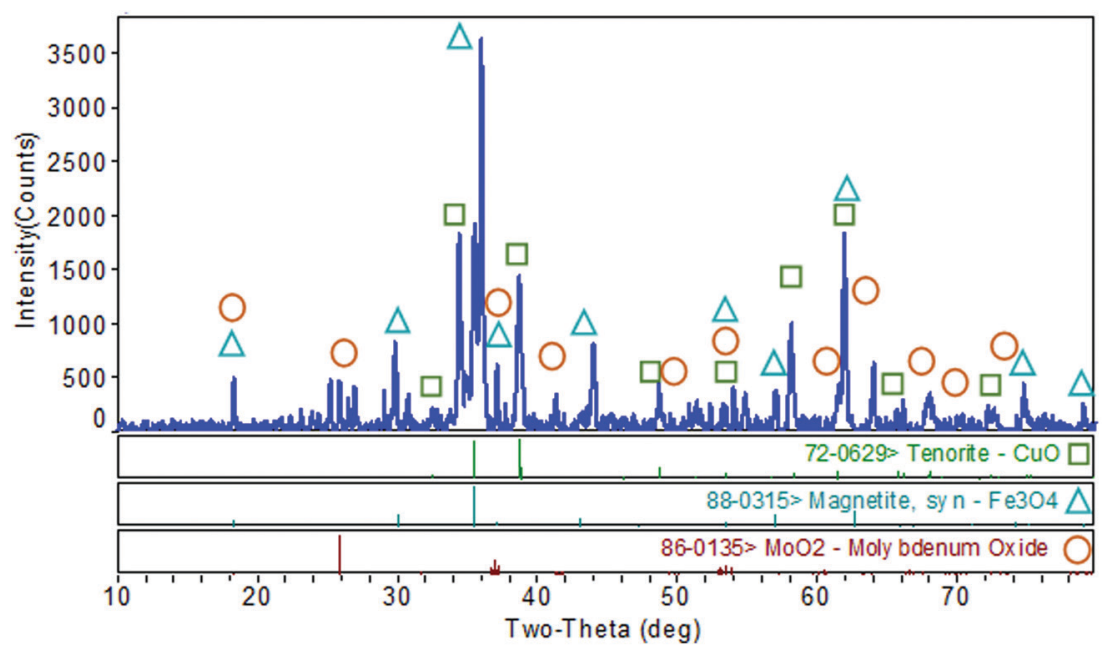

Fig. 1 XRD pattern of the $\mathrm{MoO}_{2} \cdot \mathrm{Fe}_{3} \mathrm{O}_{4} \cdot \mathrm{CuO}$ nanocomposite. 

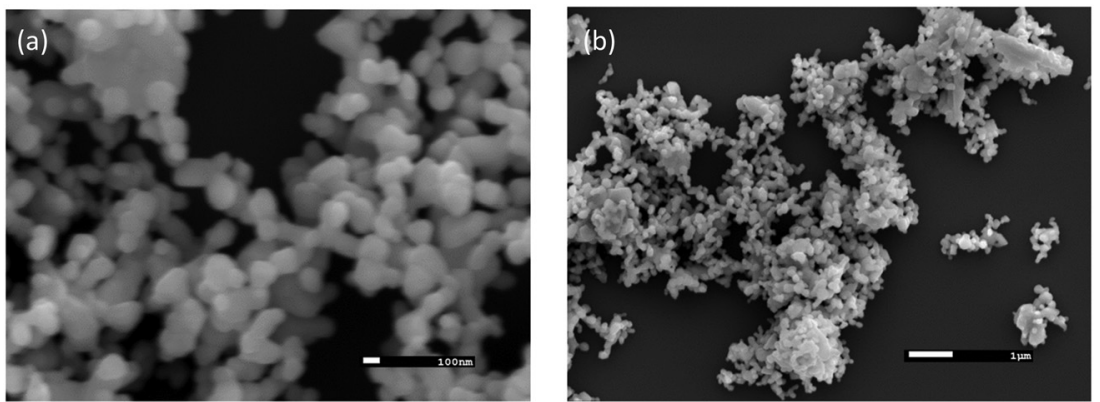

Fig. $2 \mathrm{SEM}$ image of ternary $\mathrm{MoO}_{2} \cdot \mathrm{Fe}_{3} \mathrm{O}_{4} \cdot \mathrm{CuO}$ nanocomposites at different magnification (a and b).

$\mathrm{Cu}-\mathrm{O}$ bond frequency. No peak at $873 \mathrm{~cm}^{-1}$ was found, which may indicate that there is no $\mathrm{CO}_{3}{ }^{2-}$ left in $\mathrm{MoO}_{2} \cdot \mathrm{Fe}_{3} \mathrm{O}_{4} \cdot \mathrm{CuO}$. Thus, the nanocomposite contains only oxides with little or no unknown compounds.

Zeta potential and hydrodynamic size of the $\mathrm{MoO}_{2} \cdot \mathrm{Fe}_{3} \mathrm{O}_{4} \cdot \mathrm{CuO}$ nanocomposite

The zeta potential and hydrodynamic size of the $\mathrm{MoO}_{2} \cdot \mathrm{Fe}_{3} \mathrm{O}_{4}$. $\mathrm{CuO}$ nanocomposite were studied in acidic and basic $\mathrm{pH}$ to know the size and charge in dispersed media. The hydrodynamic size, zeta potential, and polydispersity index (PDI) are listed in Table 1 . The hydrodynamic size of $\mathrm{MoO}_{2} \cdot \mathrm{Fe}_{3} \mathrm{O}_{4} \cdot \mathrm{CuO}$ in acidic $\mathrm{pH}$ and basic $\mathrm{pH}$ was found to be 1284 and $850.7 \mathrm{~nm}$. The zeta potential in acidic and basic $\mathrm{pH}$ has been observed to be -24.7 and $-24.55 \mathrm{meV}$ respectively. The results indicated that negatively charged $\mathrm{MoO}_{2} \cdot \mathrm{Fe}_{3} \mathrm{O}_{4} \cdot \mathrm{CuO}$ particles may adsorb organic compounds, dyes, and organic chemical toxins on the particle surface and perform catalytic functions.

Applications: chemical sensor study of the $\mathrm{MoO}_{2} \cdot \mathrm{Fe}_{3} \mathrm{O}_{4}$. $\mathrm{CuO} /$ Nafion/GCE assembly.

\section{Detection of $p$-NP using $\mathrm{MoO}_{2} \cdot \mathrm{Fe}_{3} \mathrm{O}_{4} \cdot \mathrm{CuO} / \mathrm{Nafion} / \mathrm{GCE}$ by the $I-V$ method}

Toxic $p$-NP in an aqueous system was determined using the $\mathrm{MoO}_{2} \cdot \mathrm{Fe}_{3} \mathrm{O}_{4}$. CuO nanocomposite modified GC electrode. When $p$-NP comes into contact with $\mathrm{MoO}_{2} \cdot \mathrm{Fe}_{3} \mathrm{O}_{4} \cdot \mathrm{CuO}$, it produces a significant response in the $I-V$ technique. The possible use of the $p$-NP sensor constructed from the $\mathrm{MoO}_{2} \cdot \mathrm{Fe}_{3} \mathrm{O}_{4} \cdot \mathrm{CuO} / \mathrm{Nafion} /$ GCE assembly was tested to detect and measure the selected toxin in phosphate buffer solution (PBS). The $\mathrm{MoO}_{2} \cdot \mathrm{Fe}_{3} \mathrm{O}_{4} \cdot \mathrm{CuO} /$ Nafion/GCE sensor exhibits several advantages such as higher stability in air, improved electro-chemical properties during the determination, versatile operation, and safe electrochemical characteristics. ${ }^{33,34}$ The probable application of the chemical sensor with $\mathrm{MoO}_{2} \cdot \mathrm{Fe}_{3} \mathrm{O}_{4} \cdot \mathrm{CuO} / \mathrm{Nafion} / \mathrm{GCE}$ was evaluated in

Table 1 Hydrodynamic size and zeta potential of the $\mathrm{MoO}_{2} \cdot \mathrm{Fe}_{3} \mathrm{O}_{4} \cdot \mathrm{CuO}$ nanocomposite

\begin{tabular}{|c|c|c|c|c|c|c|}
\hline \multirow[b]{2}{*}{ Compound } & \multicolumn{3}{|c|}{ Na-citrate buffer (pH 4.95) } & \multicolumn{3}{|c|}{ PBS buffer (pH 7.4) } \\
\hline & $\begin{array}{l}\text { Size } \\
\text { (nm) }\end{array}$ & $\begin{array}{l}\text { Zeta } \\
\text { potential }\end{array}$ & PDI & $\begin{array}{l}\text { Size } \\
(\mathrm{nm})\end{array}$ & $\begin{array}{l}\text { Zeta } \\
\text { potential }\end{array}$ & PDI \\
\hline $\mathrm{AoO}_{2} \cdot \mathrm{Fe}$ & 1234 & -24.55 & 0.66 & 850.7 & -24.7 & 0.33 \\
\hline
\end{tabular}

detail for the detection of selected compound $p$-NP in buffer solution and $\mathrm{MoO}_{2} \cdot \mathrm{Fe}_{3} \mathrm{O}_{4} \cdot \mathrm{CuO} / \mathrm{Nafion} / \mathrm{GCE}$ acted as an electron mediator during the sensing process. The $\mathrm{MoO}_{2} \cdot \mathrm{Fe}_{3} \mathrm{O}_{4} \cdot \mathrm{CuO} /$ Nafion/GCE assembly was tested as a working electrode for the construction of the proposed sensor for the targeted toxin $p$-NP. In the sensing procedure of $p$-NP in PBS solution, the applied current $v s$. potential $(I-V)$ was examined on a thin film of $\mathrm{MoO}_{2}$. $\mathrm{Fe}_{3} \mathrm{O}_{4} \cdot \mathrm{CuO} / \mathrm{Nafion} / \mathrm{GCE}$ in the working electrode, which was increased noticeably due to the adsorption of aqueous $p$-NP on the fabricated working electrode. $1.0 \mathrm{sec}$ was set as the holding period in the electrometer and an improved current $v s$. potential was detected in the time of $p$-NP determination by the fabricated chemical sensor. ${ }^{35}$ A suggested oxidation mechanism of $p$-NP is demonstrated in Scheme 1. At the time of $p$-NP oxidation by the constructed working electrode with the $\mathrm{MoO}_{2} \cdot \mathrm{Fe}_{3} \mathrm{O}_{4} \cdot \mathrm{CuO} / \mathrm{Nafion} / \mathrm{GCE}$ assembly, an enrichment of electrons in the buffer solution was detected and it caused an enhancement of the current vs. potential response during the $I-V$ measurement at ambient conditions. According to the proposed $p$-NP oxidation mechanism, at the beginning, $p$-NP was converted to 4-hydroxylaminophenol, and, in the second step, 4-hydroxylaminophenol was oxidized to 4-nitrosophenol, followed by a consequent reversible reduction, ${ }^{40}$ which are presented in eqn (i) and (ii).

$$
\begin{gathered}
\text { HO-Ph- } \mathrm{NO}_{2}+4 \mathrm{e}^{-}+\mathrm{H}^{+} \rightarrow \text { HO-Ph-NHOH }+\mathrm{H}_{2} \mathrm{O} \\
\text { HO-Ph-NHOH } \leftrightarrow \text { HO-Ph-NO }+2 \mathrm{e}^{-}+\mathrm{H}^{+}
\end{gathered}
$$

The pictorial application of the $\mathrm{MoO}_{2} \cdot \mathrm{Fe}_{3} \mathrm{O}_{4} \cdot \mathrm{CuO} / \mathrm{Nafion} /$ GCE modified electrode as a $p$-NP chemical sensor is demonstrated in Scheme 1.

A GCE was coated with a slurry of $\mathrm{MoO}_{2} \cdot \mathrm{Fe}_{3} \mathrm{O}_{4} \cdot \mathrm{CuO}$ nanomaterials. The constructed working electrode was applied for detection of $p$-NP compounds due to the oxidation in the buffer system which is proposed and presented above as per chemical reactions eqn (i) and (ii). According to the electrochemical oxidation process of targeted $p$-NP, several electrons were released to the conduction band, which enhanced the $I-V$ response of the $\mathrm{MoO}_{2} \cdot \mathrm{Fe}_{3} \mathrm{O}_{4} \cdot \mathrm{CuO} / \mathrm{Nafion} / \mathrm{GCE}$ sensors.

Fig. 3(a) shows the current responses for nine toxic chemicals, where $(1.0 \mu \mathrm{M} ; 25.0 \mu \mathrm{L}) p$-NP solution (red line) in PBS $(\mathrm{pH}=7.0)$ 


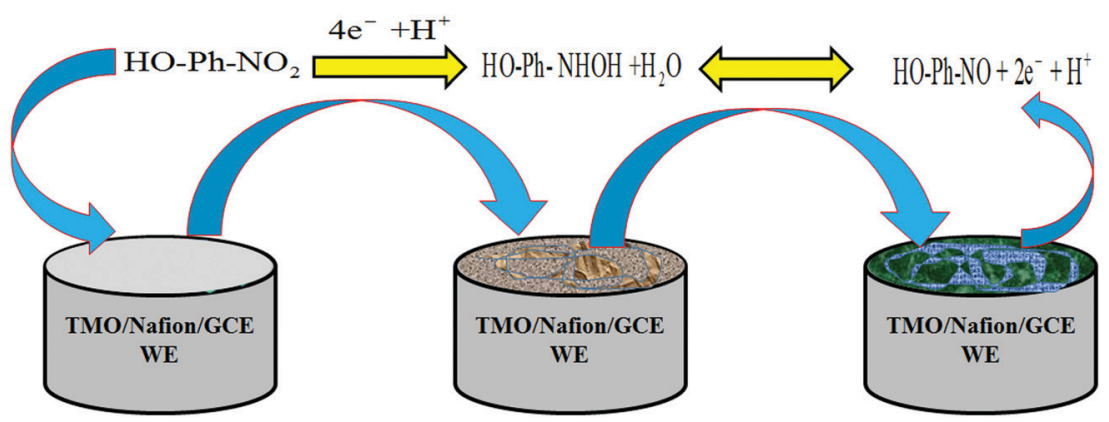

Scheme 1 The proposed mechanism in detection of $p-\mathrm{NP}$ by $\mathrm{MoO}_{2} \cdot \mathrm{Fe}_{3} \mathrm{O}_{4} \cdot \mathrm{CuO} / \mathrm{Nafion} / \mathrm{GCE}$.

produces a distinct peak at $+0.3 \mathrm{~V}$ with the $\mathrm{MoO}_{2} \cdot \mathrm{Fe}_{3} \mathrm{O}_{4} \cdot \mathrm{CuO} /$ Nafion/GCE surface. How the electrochemical property of $\mathrm{MoO}_{2} \cdot \mathrm{Fe}_{3} \mathrm{O}_{4} \cdot \mathrm{CuO}$ changes with the $\mathrm{pH}$ values was studied in PBS with pH values of 5.7 to 8.0 as in Fig. 3(b). The obtained results showed that $\mathrm{MoO}_{2} \cdot \mathrm{Fe}_{3} \mathrm{O}_{4} \cdot \mathrm{CuO}$ exhibits better electrochemical performance at different $\mathrm{pH}$ values. The electrocatalytic property of $\mathrm{MoO}_{2} \cdot \mathrm{Fe}_{3} \mathrm{O}_{4} \cdot \mathrm{CuO}$ changes with the $\mathrm{pH}$ values, which is revealed by the variation of the current response. In the $\mathrm{pH}$ optimization using $p$-NP $(1.0 \mu \mathrm{M} ; 25.0 \mu \mathrm{L})$ in PBS, pH value 7.0 produces the maximum current response. Hence, $\mathrm{pH}$ value 7.0 was used in the rest of the experimental work in this $p$-NP determination by the $\mathrm{MoO}_{2} \cdot \mathrm{Fe}_{3} \mathrm{O}_{4} \cdot \mathrm{CuO} / \mathrm{Nafion} / \mathrm{GCE}$ assembly. In the absence of target $p$-NP, the electrochemical signal intensities of the $\mathrm{MoO}_{2} \cdot \mathrm{Fe}_{3} \mathrm{O}_{4} \cdot \mathrm{CuO} / \mathrm{GCE}$ sensor probe at different $\mathrm{pH}$ values are measured and the signal is found to not significantly change in identical conditions (Fig. S4a, ESI $\dagger$ ). The signal intensities of the $\mathrm{MoO}_{2} \cdot \mathrm{Fe}_{3} \mathrm{O}_{4} \cdot \mathrm{CuO} / \mathrm{GCE}$ sensor probe at different times (in the absence of $p$-NP) are also evaluated in identical conditions (Fig. S4b, ESI $\dagger$ ). It is observed that no significant changes are found in the electrochemical response for elongated time in the absence of target analyte $p$-NP. The current intensities using $p$-NP $(1.0 \mu \mathrm{M} ; 25.0 \mu \mathrm{L})$ in PBS $(5.0 \mathrm{~mL}$, $\mathrm{pH}=7.0$ ) for the bare GCE (blue line) and $\mathrm{MoO}_{2} \cdot \mathrm{Fe}_{3} \mathrm{O}_{4} \cdot \mathrm{CuO}$ fabricated GCE (red line) are given in Fig. 3(c). $\mathrm{MoO}_{2} \cdot \mathrm{Fe}_{3} \mathrm{O}_{4}$. $\mathrm{CuO} / \mathrm{Nafion} / \mathrm{GCE}$ produces a much better response than the bare GCE, which demonstrates the excellent electrochemical property of $\mathrm{MoO}_{2} \cdot \mathrm{Fe}_{3} \mathrm{O}_{4} \cdot \mathrm{CuO}$ as a selective $p$-NP sensor. Fig. 3(d) shows the current response of the $\mathrm{MoO}_{2} \cdot \mathrm{Fe}_{3} \mathrm{O}_{4} \cdot \mathrm{CuO}$ fabricated GCE in the absence of $p$-NP (blue line) and the presence of $p$-NP (red line; $1.0 \mu \mathrm{M} ; 25.0 \mu \mathrm{L}$ ) in $5.0 \mathrm{~mL}$ of PBS. With $p$-NP, a remarkable increase of the current response indicates the $p$-NP sensing capability of the proposed $\mathrm{MoO}_{2} \cdot \mathrm{Fe}_{3} \mathrm{O}_{4} \cdot \mathrm{CuO} / \mathrm{Nafion} / \mathrm{GCE}$ sensor. The $I-t$ response for $p$-NP $(1.0 \mu \mathrm{M} ; 25.0 \mu \mathrm{L})$ in $5.0 \mathrm{~mL}$ of PBS solution using the $\mathrm{MoO}_{2} \cdot \mathrm{Fe}_{3} \mathrm{O}_{4} \cdot \mathrm{CuO}$ nanostructure fabricated
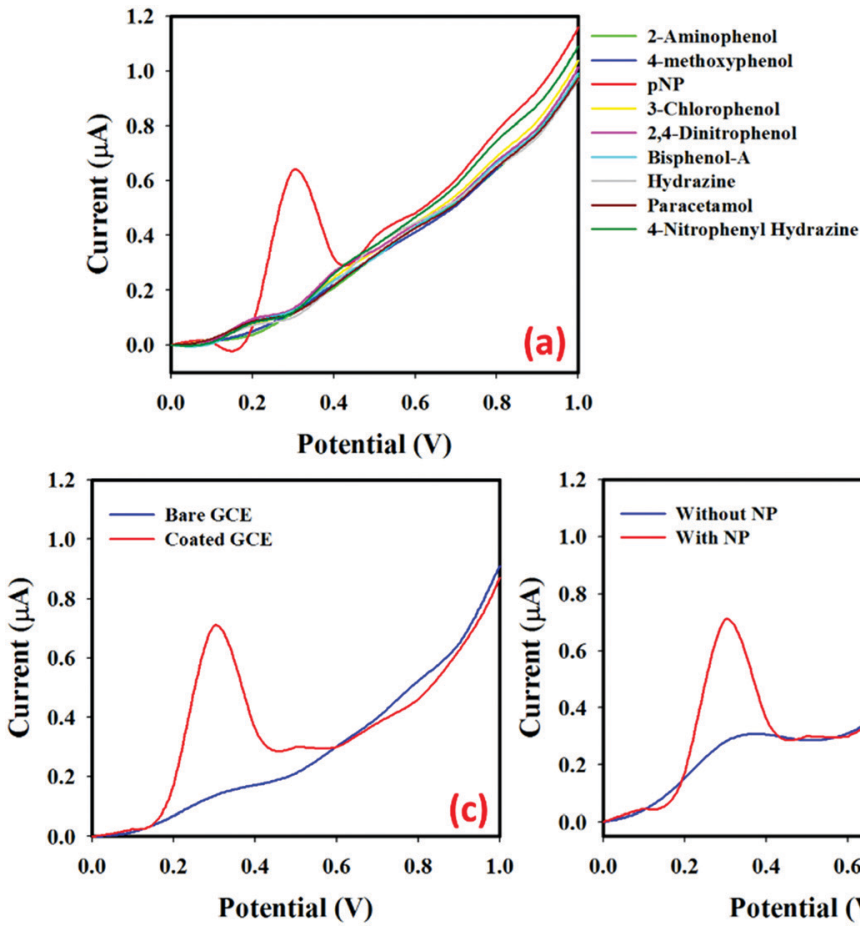
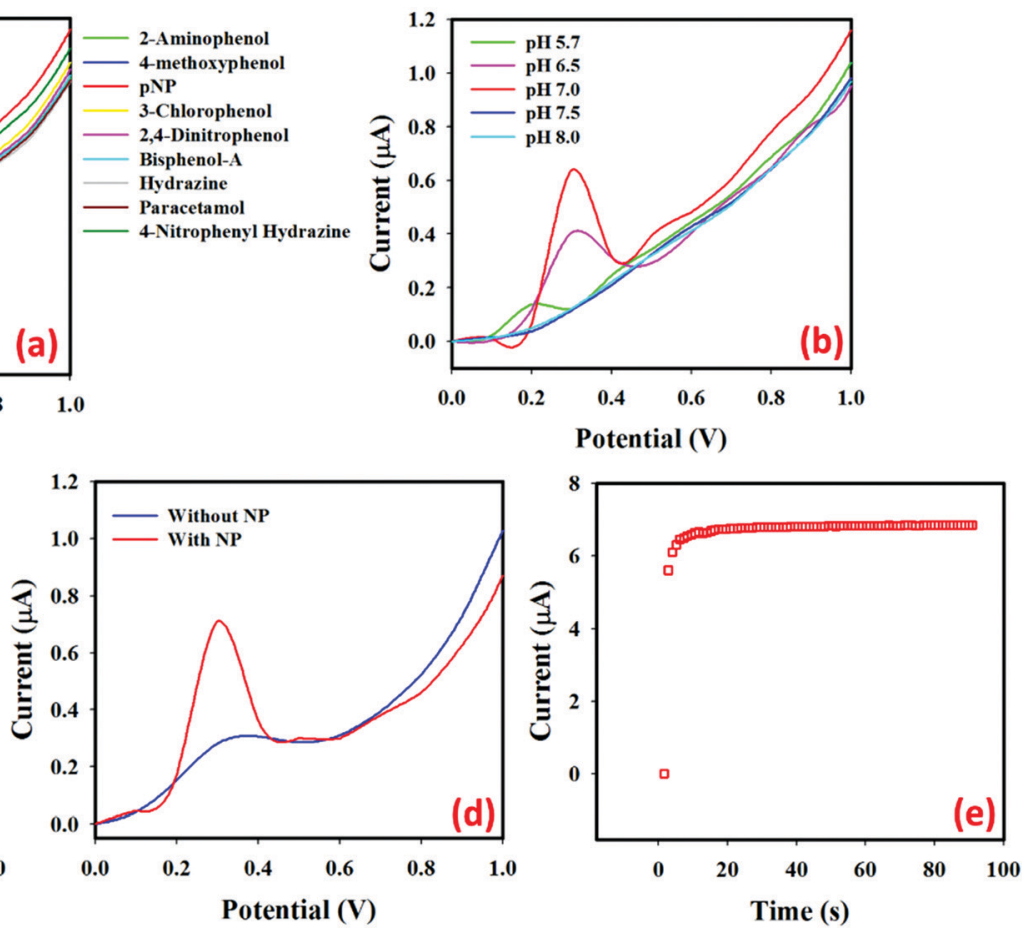

Fig. 3 I-V responses: (a) selectivity study using nine interferents, (b) $\mathrm{pH}$ variation; (c) bare $\mathrm{GCE}$ and $\mathrm{MoO}_{2} \cdot \mathrm{Fe}_{3} \mathrm{O}_{4} \cdot \mathrm{CuO} / \mathrm{GCE}$, and (d) without and with the presence of $p-\mathrm{NP}(1.0 \mu \mathrm{M} ; 25.0 \mu \mathrm{L})$, and (e) current variation with time for $\mathrm{MoO}_{2} \cdot \mathrm{Fe}_{3} \mathrm{O}_{4}$. CuO/Nafion/GCE in $1.0 \mu \mathrm{M} ; 25.0 \mu \mathrm{L} p$-NP. 

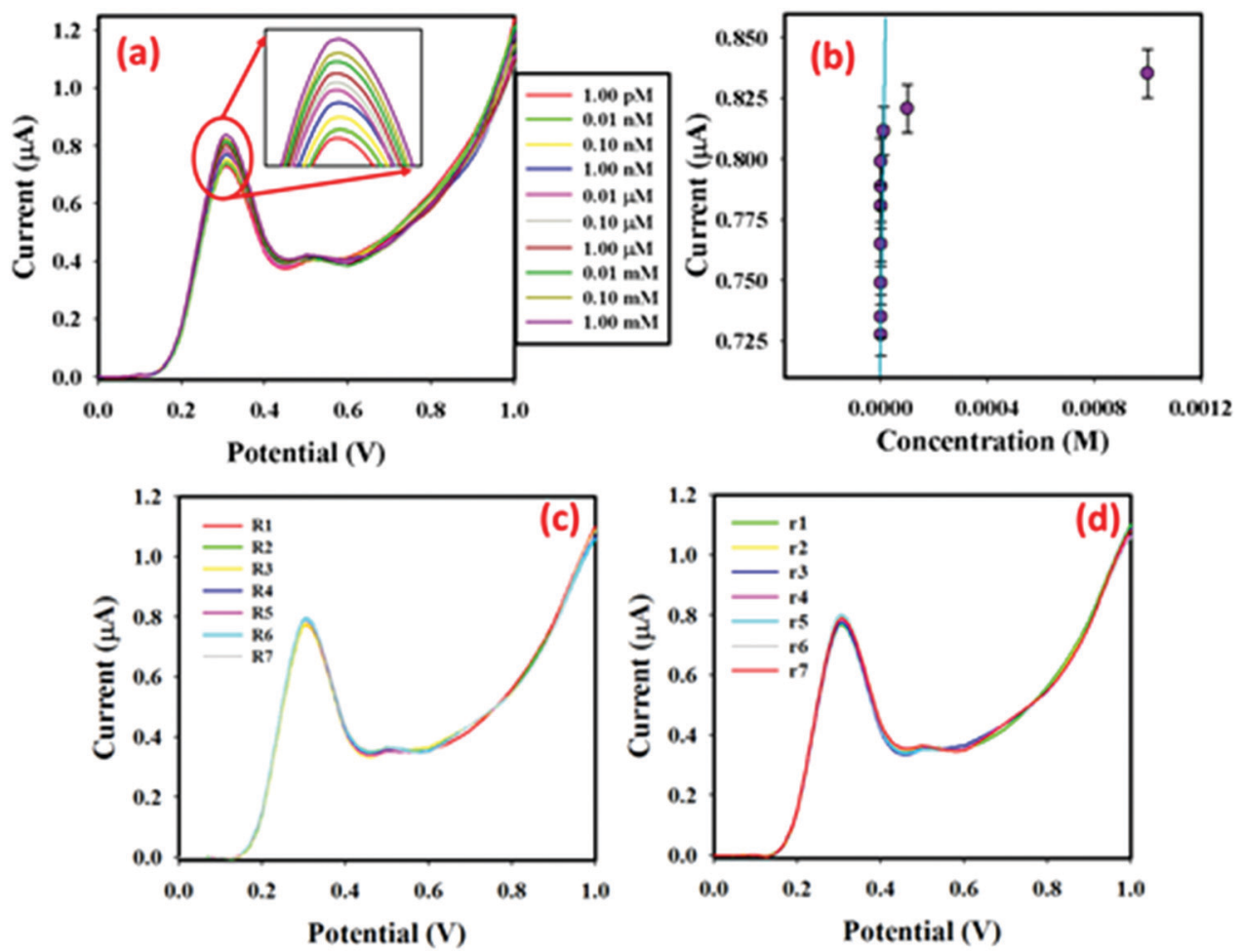

Fig. 4 (a) Current variations for different concentrations $\left(1.0 \mathrm{pM}\right.$ to $1.0 \mathrm{mM}$ ) of aqueous $p-\mathrm{NP}$ in 0.0 to $+1.0 \mathrm{~V}$, (b) calibration plot of the $\mathrm{MoO}_{2} \cdot \mathrm{Fe}_{3} \mathrm{O}_{4} \cdot \mathrm{CuO}$ fabricated GCE at $+0.3 \mathrm{~V}$, (c) repeatability using different WEs (0.1 $\mu \mathrm{M}, 25.0 \mu \mathrm{L} p-\mathrm{NP} ; 5.0 \mathrm{~mL}, 0.1 \mathrm{M} \mathrm{PBS}$ at pH 7.0), and (d) reproducibility using the same WE $(0.1 \mu \mathrm{M}, 25.0 \mu \mathrm{L} p-\mathrm{NP} ; 5.0 \mathrm{~mL}, 0.1 \mathrm{M}$ PBS at $\mathrm{pH}$ 7.0).

GCE as a working electrode is shown in Fig. 3(e). With $p$-NP $(1.0 \mu \mathrm{M} ; 25.0 \mu \mathrm{L})$ in $5.0 \mathrm{~mL}$ of PBS, a constant current response was obtained in approximately 10 seconds. The $p$-NP chemical sensor is also optimized with various single metal oxides (i.e.; $\mathrm{CuO}, \mathrm{Fe}_{3} \mathrm{O}_{4}$, and $\mathrm{MoO}_{2}$ ) and compared with the $\mathrm{MoO}_{2} \cdot \mathrm{Fe}_{3} \mathrm{O}_{4} \cdot \mathrm{CuO}$ nanostructure in identical conditions (Fig. S4c, ESI $\dagger$ ). The highest current is observed with the $\mathrm{MoO}_{2} \cdot \mathrm{Fe}_{3} \mathrm{O}_{4} \cdot \mathrm{CuO}$ nanostructure/GCE sensor probe compared to the only $\mathrm{CuO}, \mathrm{Fe}_{3} \mathrm{O}_{4}$, and $\mathrm{MoO}_{2}$ modified individual material.

In $5.0 \mathrm{~mL}$ PBS, low (1.0 pM) to high $(1.0 \mathrm{mM})$ concentration $p$-NP solutions $(25.0 \mu \mathrm{L})$ were injected sequentially and the surface current response variations were studied after every injection. The $I-V$ responses from the $\mathrm{MoO}_{2} \cdot \mathrm{Fe}_{3} \mathrm{O}_{4} \cdot \mathrm{CuO}$ fabricated GCE surface were estimated using an aqueous $p$-NP solution of different concentrations (1.0 pM to $1.0 \mathrm{mM})$, given in Fig. 4(a) (the inset shows the magnification peak current at $0.3 \mathrm{~V}$ ). It showed that when the potential increases, the $I-V$ responses are also increased for the $\mathrm{MoO}_{2} \cdot \mathrm{Fe}_{3} \mathrm{O}_{4} \cdot \mathrm{CuO}$ fabricated GCE sensor. It was also observed that, from dilute $(1.0 \mathrm{pM})$ to concentrated $(1.0 \mathrm{mM}) p$-NP solution, the $I-V$ responses also increased regularly. Aqueous $p$-NP $(1.0 \mathrm{pM}$ to $1.0 \mathrm{mM}$ ) was taken to select the limit of detection (LOD) of the developed sensor. The calibration plot (at $+0.3 \mathrm{~V}$ ) for the full concentration range is given in Fig. 4(b). A higher sensitivity value of $5.2430 \mu \mathrm{A} \mu \mathrm{M}^{-1} \mathrm{~cm}^{-2}$ was estimated from the calibration plot. From the calibration plot, the linear dynamic range of the developed $\mathrm{MoO}_{2} \cdot \mathrm{Fe}_{3} \mathrm{O}_{4} \cdot \mathrm{CuO} / \mathrm{GCE}$ sensor was attained as $1.0 \mathrm{pM}$ to $0.01 \mathrm{mM}\left(r^{2}=0.9995\right)$, and the LOD was estimated as
$0.2 \mathrm{pM}[3 \times$ noise $(\mathrm{N}) /$ slope $(\mathrm{S})]$. Fig. 4(c) shows the reproducibility of the current response with the $\mathrm{MoO}_{2} \cdot \mathrm{Fe}_{3} \mathrm{O}_{4} \cdot \mathrm{CuO}$ fabricated GCE with $25.0 \mu \mathrm{L}$ of $0.1 \mu \mathrm{M} p$-NP using seven distinct working electrodes in run R1 to R7 under the same experimental conditions. The almost similar current responses in all seven experiments confirm the outstanding reproducibility of the sensor $(\mathrm{RSD}=4.17 \%, n=7)$. Fig. $4(\mathrm{~d})$ presents the repeatability where the same working electrode was used in run R1-R7. The almost similar $I-V$ responses in the seven repeated experiments demonstrate the outstanding repeatability of the sensor $(\mathrm{RSD}=$ $3.85 \%, n=7)$. With the same working electrode in different solutions with the same conditions, the $I-V$ response decreases

Table 2 Analysis of some environmental samples with $\mathrm{MoO}_{2} \cdot \mathrm{Fe}_{3} \mathrm{O}_{4} \cdot \mathrm{CuO} /$ Nafion/GCE by the electrochemical process

\begin{tabular}{|c|c|c|c|c|}
\hline $\begin{array}{l}\text { Real } \\
\text { sample }\end{array}$ & $\begin{array}{l}p \text {-NP con- } \\
\text { centration }^{a} \\
\text { added }\end{array}$ & $\begin{array}{l}p \text {-NP concentration }{ }^{a} \\
\text { determined }{ }^{b} \text { by } \\
\mathrm{MoO}_{2} \cdot \mathrm{Fe}_{3} \mathrm{O}_{4} \cdot \mathrm{CuO} / \\
\text { Nafion/GCE }\end{array}$ & $\begin{array}{l}\text { Recovery } \\
(\%)\end{array}$ & $\begin{array}{l}\operatorname{RSD}^{c} \\
(\%)(n=3)\end{array}$ \\
\hline S1 & $2.000 \mathrm{nM}$ & $2.102 \mathrm{nM}$ & 105.1 & 3.1 \\
\hline S1 & $2.000 \mu \mathrm{M}$ & $2.056 \mu \mathrm{M}$ & 102.8 & 2.9 \\
\hline $\mathrm{S} 2$ & $2.000 \mathrm{nM}$ & $2.036 \mathrm{nM}$ & 101.8 & 2.8 \\
\hline $\mathrm{S} 2$ & $2.000 \mu \mathrm{M}$ & $2.006 \mu \mathrm{M}$ & 100.3 & 3.4 \\
\hline
\end{tabular}

S1 and S2: real water samples collected from an industrial effluent treatment plant and Safa drinking water bottle respectively, Jeddah, Saudi Arabia. ${ }^{a}$ Mean of three repeated determinations $(\mathrm{S} / \mathrm{N}=3)$ with $\mathrm{MoO}_{2} \cdot \mathrm{Fe}_{3} \mathrm{O}_{4} \cdot \mathrm{CuO} / \mathrm{Nafion} / \mathrm{GCE} .{ }^{b}$ Concentration of $p$-NP determined/ concentration of $p$-NP taken. ${ }^{c}$ The relative standard deviation value indicates the precision among three repeated determinations. 
Table 3 Comparison of sensor analytical parameters of other nanostructure materials with the $\mathrm{MoO}_{2} \cdot \mathrm{Fe}_{3} \mathrm{O}_{4} \cdot \mathrm{CuO} / \mathrm{Nafion} / \mathrm{GCE}$ sensor probe using the electrochemical method for the detection of $p$-NP

\begin{tabular}{|c|c|c|c|c|c|}
\hline Sensor material & Method & LDR & LOD & Sensitivity & Ref. \\
\hline BDAC & LSV & Up to $500 \mu \mathrm{M}$ & $0.16 \mu \mathrm{M}$ & $5.810 \mu \mathrm{A} \mu \mathrm{M}^{-1} \mathrm{~cm}^{-2}$ & 42 \\
\hline $\mathrm{Fe}_{3} \mathrm{O}_{4} /$ graphene & DPV & 0.01 to $0.10 \mathrm{mM}$ & $0.004 \mathrm{mM}$ & $8.067 \times 10^{-5} \mu \mathrm{A} \mathrm{mM}{ }^{-1}$ & 43 \\
\hline $\mathrm{NiO}-\mathrm{CeO}_{2}$ & $\mathrm{CV}$ & 1 to $20 \mu \mathrm{M}$ & $2.48 \mu \mathrm{M}$ & $3.68 \mathrm{~A} \mu \mathrm{M}^{-1} \mathrm{~cm}^{-2}$ & 45 \\
\hline $\mathrm{MoO}_{2} \cdot \mathrm{Fe}_{3} \mathrm{O}_{4} \cdot \mathrm{CuO}$ & $I-V$ & $1.0 \mathrm{pM}$ to $0.01 \mathrm{mM}$ & $0.2 \mathrm{pM}$ & $5.2430 \mu \mathrm{A} \mu \mathrm{M}^{-1} \mathrm{~cm}^{-2}$ & This work \\
\hline
\end{tabular}

TLISS $=$ tremella-like indium silver sulfide modified GCE, ABPGH $=$ acetylene blackpaste and graphene hybrid, BDAC $=$ biomass derived activated carbons.

slightly. This may be because of the fall of the number of active sites in $\mathrm{MoO}_{2} \cdot \mathrm{Fe}_{3} \mathrm{O}_{4} \cdot \mathrm{CuO}$ after each run.

\section{Real sample analysis by the $\mathrm{MoO}_{2} \cdot \mathrm{Fe}_{3} \mathrm{O}_{4} \cdot \mathrm{CuO} / \mathrm{Nafion} / \mathrm{GCE}$ sensor}

To confirm the functionality of the proposed sensor material $\mathrm{MoO}_{2} \cdot \mathrm{Fe}_{3} \mathrm{O}_{4} \cdot \mathrm{CuO}, \quad \mathrm{MoO}_{2} \cdot \mathrm{Fe}_{3} \mathrm{O}_{4} \cdot \mathrm{CuO} / \mathrm{Nafion} / \mathrm{GCE}$ had been employed to determine $p$-NP in industrial effluent water and drinking water from a plastic bottle after 7 days of sunlight irradiation kept inside a car (S2). For this, we use the standard addition method to verify the accuracy of the aqueous $p$-NP determination. $25.0 \mu \mathrm{L}$ of aqueous $p$-NP of different concentrations and equal amounts of real samples were mixed and analyzed in PBS (5.0 mL, pH 7.0) with $\mathrm{MoO}_{2} \cdot \mathrm{Fe}_{3} \mathrm{O}_{4} \cdot \mathrm{CuO} / \mathrm{GCE}$ as a WE. Table 2 presents the obtained outcomes, which demonstrated that the $\mathrm{MoO}_{2} \cdot \mathrm{Fe}_{3} \mathrm{O}_{4} \cdot \mathrm{CuO} / \mathrm{GCE}$ modified sensor exhibited a quantitative $(\sim 100 \%)$ recovery of $p$-NP. So, we can conclude that the $I-V$ method can be an appropriate and reliable technique in analyzing real samples using the $\mathrm{MoO}_{2}$. $\mathrm{Fe}_{3} \mathrm{O}_{4} \cdot \mathrm{CuO} / \mathrm{Nafion} / \mathrm{GCE}$ assembly.

The $I-V$ responses in the $p$-NP measurements mostly depend on the size, porosity, and morphology of the nanomaterials. When the $\mathrm{MoO}_{2} \cdot \mathrm{Fe}_{3} \mathrm{O}_{4} \cdot \mathrm{CuO}$ surface comes into contact with the reducing $p$-NP, a surface-mediated oxidation reaction takes place. Oxidation of $p$-NP provides electrons to the $\mathrm{MoO}_{2} \cdot \mathrm{Fe}_{3} \mathrm{O}_{4}$. $\mathrm{CuO}$ nanocomposite surface, which ultimately enhances the conductance of the $\mathrm{MoO}_{2} \cdot \mathrm{Fe}_{3} \mathrm{O}_{4} \cdot \mathrm{CuO} / \mathrm{Nafion} / \mathrm{GCE}$ assembly. Consequently, when the potential increases, the $I-V$ response also increases. The $\mathrm{MoO}_{2} \cdot \mathrm{Fe}_{3} \mathrm{O}_{4} \cdot \mathrm{CuO} /$ Nafion/GCE sensor has also displayed consistency and stability. Overall, the proposed $\mathrm{MoO}_{2} \cdot \mathrm{Fe}_{3} \mathrm{O}_{4} \cdot \mathrm{CuO} / \mathrm{Nafion} / \mathrm{GCE}$ sensor for $p$-NP detection showed better performance than others as shown in Table $3 .^{41-45}$

\section{Conclusions}

$\mathrm{MoO}_{2} \cdot \mathrm{Fe}_{3} \mathrm{O}_{4}$. CuO was synthesized by the coprecipitation method. $\mathrm{MoO}_{2} \cdot \mathrm{Fe}_{3} \mathrm{O}_{4} \cdot \mathrm{CuO}$ was characterized by several techniques including XRD, SEM-EDS, hydrodynamic size and zeta-potential analysis, and FTIR. The average particle size of the nanocomposite was determined to be $34.85 \mathrm{~nm}$. The surface morphology of the composite was observed in the SEM study. The zeta potential of $\mathrm{MoO}_{2} \cdot \mathrm{Fe}_{3} \mathrm{O}_{4} \cdot \mathrm{CuO}$ in acidic and basic $\mathrm{pH}$ has been observed to be -24.7 and $-24.55 \mathrm{meV}$ respectively. $\mathrm{A}^{\mathrm{MoO}} \cdot \mathrm{Fe}_{3} \mathrm{O}_{4} \cdot \mathrm{CuO} / \mathrm{Nafion} /$ GCE electrode was successfully employed as a chemical sensor for the determination of aqueous para-nitrophenol. The fabricated $p$-NP chemical sensor based on $\mathrm{MoO}_{2} \cdot \mathrm{Fe}_{3} \mathrm{O}_{4} \cdot \mathrm{CuO}$ coated on a GCE showed a very efficient electron mediator property in the oxidation of $p$-NP in the PBS system. The proposed $\mathrm{MoO}_{2} \cdot \mathrm{Fe}_{3} \mathrm{O}_{4}$. $\mathrm{CuO} / \mathrm{Nafion} / \mathrm{GCE}$ sensor for $p$-NP exhibits a high sensitivity $\left(5.2430 \mu \mathrm{A} \mathrm{nM}^{-1} \mathrm{~cm}^{-2}\right)$ and ultra-low LOD $=0.2 \mathrm{pM}$ with an excellent linear response $\left(r^{2}: 0.9995\right)$ for a wide range of concentrations in a short response time. It initiated a new route in developing an effective chemical sensor using nanostructured nanomaterials for a sustainable and safe environment.

\section{Conflicts of interest}

We declare that there is no conflict of interest.

\section{Acknowledgements}

Md Abdus Subhan acknowledges Fulbright USA for offering a Fulbright Visiting Scholar Award 2018-2019 for 9 months. MOE (Ministry of Education), Bangladesh, Grant (PS 14290) is gratefully acknowledged for support. Center of Excellence for Advanced Materials Research (CEAMR), King Abdulaziz University, Jeddah, Saudi Arabia, is highly acknowledged for the lab facilities and instrumental support.

\section{References}

1 J. F. Brazdil, Bulk metal oxides, in Characterization of Catalytic Materials, ed. I. E. Wachs, ButterworthHeinemann, Boston, Massachusetts, 1992, pp. 47-68.

2 I. E. Wachs and K. Segawa, Supported metal oxides, in Characterization of Catalytic Materials, ed. I. E. Wachs, ButterworthHeinemann, Boston, Massachusetts, 1992, pp. 69-88.

3 C. L. Thomas, Catalytic Processes and Proven Catalysts, Academic Press, New York, 1970.

4 S. J. Singh and R. V. Jayaram, Tetrahedron Lett., 2008, 49, 4249.

5 M. M. Rahman, A. Umar and K. Sawada, Development of amperometric glucose biosensor based on glucose oxidase co-immobilized with multi-walled carbon nanotubes at low potential, Sens. Actuators, B, 2009, 137, 327.

6 D. I. Enache, J. K. Edwards, P. Landon, B. Solsona-Espriu, A. F. Carley, A. A. Herzing, M. Watanabe, C. J. Kiely, D. W. Knight and G. J. Hutchings, Science, 2006, 311, 362. 
7 X. Guo, H. Zhou, T. Fan and D. Zhang, Electrochemical detection of p-nitrophenol on surface imprinted gold with lamellar-ridge architecture, Sens. Actuators, B, 2015, 220, 33-39.

8 Z. C. Xiang, Q. Zhang, Z. Zhang, X. J. Xu and Q. B. Wang, Preparation and photoelectric properties of semiconductor $\mathrm{MoO}_{2}$ micro/nanospheres with wide bandgap, Ceram. Int., 2015, 41, 977-981.

9 R. J. Elliot, Phys. Rev., 1957, 108, 1384.

10 C. Julien, A. Khelfa, O. M. Hussain and J. A. Nazri, J. Cryst. Growth, 1995, 156, 235.

11 A. Fakhri and P. Afshar Nejad, J. Photochem. Photobiol., B, 2016, 159, 211.

12 M. A. Subhan, T. P. Rifat, P. C. Saha, M. M. Alam, A. M. Asiri, M. M. Rahman and J. Uddin, Enhanced visible light-mediated photocatalysis, antibacterial functions and fabrication of a 3-chlorophenol sensor based on ternary $\mathrm{Ag}_{2} \mathrm{O} \cdot \mathrm{SrO} \cdot \mathrm{CaO}, \mathrm{RSC}$ Adv., 2020, 10(19), 11274-11291.

13 M. A. Subhan, P. C. Saha, S. A. Sumon, J. Ahmed, A. M. Asiri, M. M. Rahman and Al-M Mamun, Enhanced photocatalytic activity and ultrasensitive benzaldehyde sensing performance of $\mathrm{a} \mathrm{SnO}_{2} \cdot \mathrm{ZnO} \cdot \mathrm{TiO}_{2}$ nanomaterial, RSC Adv., 2018, 8, 33048-33058.

14 M. A. Subhan, S. S. Jhuma, P. C. Saha, M. M. Alam, A. M. Asiri, M. Al- Mamun, S. A. Attia, T. H. Emon, A. K. Azad and M. M. Rahman, Efficient selective 4-aminophenol sensing and antibacterial activity of ternary $\mathrm{Ag}_{2} \mathrm{O}_{3} \cdot \mathrm{SnO}_{2} \cdot \mathrm{Cr}_{2} \mathrm{O}_{3}$ nanoparticles, New J. Chem., 2019, 43, 10352.

15 M. A. Subhan, S. S. Jhuma, P. C. Saha, J. Ahmed, A. M. Asiri, T. P. Rifat, T. Raihan, A. K. Azad and M. M. Rahman, Photocatalysis, enhanced anti-bacterial performance and discerning thiourea sensing of $\mathrm{Ag}_{2} \mathrm{O} \cdot \mathrm{SnO}_{2} \cdot \mathrm{TiO}_{2}$ heterostructure, J. Environ. Chem. Eng., 2020, 8, 104051.

16 M. A. Subhan, P. C. Saha, M. M. Rahman, J. Ahmed, A. M. Asiri and M. A. Mamun, Fabrication of a 2,4dinitrophenol sensor based on $\mathrm{Fe}_{3} \mathrm{O}_{4}$ @Ag@Ni nanomaterials and studies on their antibacterial properties, New J. Chem., 2018, 42, 872.

17 X.-Q. Qiao, Z.-W. Zhang, F.-Y. Tian, D.-F. Hou, Z.-F. Tian, D. Li and Q. Zhang, Enhanced catalytic reduction of $p$-nitrophenol on ultrathin $\mathrm{MoS}_{2}$ nanosheets decorated noble-metal nanoparticles, Cryst. Growth Des., 2017, 17(6), 3538-3547.

18 X.-Q. Qiao, Z.-W. Zhang, D.-F. Hou, D.-S. Li, Y. Liu, Y.-Q. Lan, J. Zhang, P. Feng and X. Bu, Tunable $\mathrm{MoS}_{2} /$ $\mathrm{SnO}_{2} \mathrm{P}-\mathrm{N}$ Heterojunctions for an Efficient Trimethylamine Gas Sensor and 4-Nitrophenol Reduction Catalyst, ACS Sustainable Chem. Eng., 2018, 6, 12375-12384.

19 Z. Liu, J. Du, C. Qiu, L. Huang, H. Ma, D. Shen and Y. Ding, Electrochemical sensor for detection of $p$-nitrophenol based on nanoporous gold, Electrochem. Commun., 2009, 11, 1365-1368.

20 H. Yin, Y. Zhou, S. Ai, L. Cui and L. Zhu, Electrochemical determination of 2-nitrophenol in water samples using Mg-Al-SDS hydrotalcite-like clay modified glassy carbon electrode, Electroanalysis, 2010, 22(10), 1136-1142.
21 X. Huang, N. Qiu and D. Yuan, Direct enrichment of phenols in lake and sea water by stir bar sorption extraction based on poly (vinylpyridine-ethylene dimethacrylate) monolithic material and liquid chromatographic analysis, J. Chromatogr., 2008, A1194, 134-138.

22 X. Guo, Z. Wang and S. Zhou, The separation and determination of nitrophenol isomers by high-performance capillary zone electrophoresis, Talanta, 2004, 64, 135-139.

23 A. Niazi and A. Yazdanipour, Spectrophotometric simultaneous determination of nitrophenol isomers by orthogonal signal correction and partial least squares, J. Hazard. Mater., 2007, 146, 421-427.

24 H. Yin, Y. Zhou, S. Ai, X. Liu, L. Zhu and L. Lu, Electrochemical oxidative determination of 4-nitrophenol based on a glassy carbon electrode modified with a hydroxyapatite nano powder, Microchim. Acta, 2010, 169, 87-92.

25 K. Giribabu, R. Suresh, R. Manigandan, S. Munusamy, S. P. Kumar, S. Muthamizh and V. Narayanan, Nanomolar determination of 4-nitrophenol based on a poly(methylene blue)-modified glassy carbon electrode, Analyst, 2013, 138, 5811-5818.

26 M. K. Alam, M. M. Rahman, M. Abbas, S. R. Torati, A. M. Asiri, D. Kim and C. G. Kim, Ultra-sensitive 2-nitrophenol detection based on reduced graphene oxide/ ZnO nanocomposites, J. Electroanal. Chem., 2017, 788, 66-73.

27 H. Yin, Y. Zhou, S. Ai, Q. Ma, L. Zhu and L. Lu, Electrochemical oxidation determination and voltammetric behaviour of 4-nitrophenol based on $\mathrm{Cu}_{2} \mathrm{O}$ nanoparticles modified glassy carbon electrode, Int. J. Environ. Anal. Chem., 2012, 92(6), 742-754.

28 Y. Tang, R. Huang, C. Liu, S. Yang, Z. Lu and S. Luo, Electrochemical detection of 4-nitrophenol based on a glassy carbon electrode modified with a reduced graphene oxide/Au nanoparticle composite, Anal. Methods, 2013, 5, 5508-5514.

29 J. Li, D. Kuang, Y. Feng, F. Zhang, Z. Xu and M. Liu, A graphene oxide-based electrochemical sensor for sensitive determination of 4-nitrophenol, J. Hazard. Mater., 2012, 201-202, 250-259.

30 K. Chen, Z.-L. Zhang, Y.-M. Liang, W. Liu and A. GrapheneBased, Electrochemical Sensor for Rapid Determination of Phenols in Water, Sensors, 2013, 13, 6204-6216.

31 A. Arvinte, M. Mahosenaho, M. Pinteala, A.-M. Sesay and V. Virtanen, Electrochemical oxidation of $p$-nitrophenol using graphene-modified electrodes, and a comparison to the performance of MWNT-based electrodes, Microchim. Acta, 2011, 174, 337-343.

32 M. M. Rahman, M. M. Alam, A. M. Asiri and M. A. Islam, Fabrication of selective chemical sensor with ternary $\mathrm{ZnO} /$ $\mathrm{SnO}_{2} / \mathrm{Yb}_{2} \mathrm{O}_{3}$ nanoparticles, Talanta, 2017, 170, 215-223.

33 M. A. Subhan, P. C. Saha, M. M. Rahman, M. A. R. Akand, A. M. Asiri and M. Al-Mamun, Enhanced photocatalytic activity and chemical sensor development based on ternary $\mathrm{B}_{2} \mathrm{O}_{3} \cdot \mathrm{Zn}_{6} \mathrm{Al}_{2} \mathrm{O}_{9} \cdot \mathrm{ZnO}$ nanomaterials for environmental safety, New J. Chem., 2017, 41(15), 7220-7231. 
34 M. A. Subhan, T. Ahmed, P. Sarker, T. T. Pakkanen, M. Suvantoc, M. Horimoto and H. Nakata, J. Lumin., 2014, 148, 98.

35 Md A. Subhan, M. R. Awal, T. Ahmed and M. Younus, Acta Metall. Sin., 2014, 27(2), 223-232.

36 H. H. Kung, Stud. Surf. Sci. Catal., 1989, 45, 1.

37 N. Dukstiene, D. Sinkeviciute and A. Guobiene, Cent. Eur. J. Chem., 2012, 10(4), 1106-1118.

38 G. Gundiah and C. N. R. Rao, Solid State Sci., 2000, $2,877$.

39 Y. Haldorai, K. Giribabu, S. K. Hwang, C. H. Kwak, Y. S. Huh and Y. K. Han, Facile synthesis of a-MnO${ }_{2}$ nanorod/ graphene nanocomposite paper electrodes using a 3D precursor for supercapacitors and sensing platform to detect 4-nitrophenol, Electrochem. Acta., 2016, 222, 717-727.

40 M. M. Rahman, S. B. Khan, A. M. Asiri and A. G. Al-Sehemi, Chemical sensor development based on polycrystalline gold electrode embedded low-dimensional $\mathrm{Ag}_{2} \mathrm{O}$ nanoparticles, Electrochem. Acta., 2013, 112, 422-430.
41 Q. He, Y. Tian, Y. Wu, J. Liu, G. Li, P. Deng and D. Chen, Facile and Ultrasensitive Determination of 4-Nitrophenol Based on Acetylene Black Paste and Graphene Hybrid Electrode, Nanomaterials, 2019, 9, 429.

42 R. Madhu, C. Karuppiah, S.-M. Chen, P. Veerakumar and S.-B. Liu, Electrochemical detection of 4-nitrophenol based on biomass derived activated carbons, Anal. Methods, 2014, 6, 5274-5280.

43 M. Sarno and E. Ponticorvo, $\mathrm{Fe}_{3} \mathrm{O}_{4} /$ Graphene Electrode for the Electrochemical Detection of 4-Nitrophenol, Chem. Eng. Trans., 2020, 79, 427.

44 P. Chen, Y. Shi, X. Li, T. Wang, M. Zhou, E. Tian, W. Wang, H. Jiang and H. Shu, Highly Effective Detection of 4-Nitrophenol by Tremella-like Indium Silver Sulfide Modified GCE, Int. J. Electrochem. Sci., 2018, 13, 6158-6168.

45 N. Ahmad, M. Alam and R. Wahab, Synthesis of $\mathrm{NiO}-\mathrm{CeO}_{2}$ nanocomposite for electrochemical sensing of perilous 4-nitrophenol, J. Mater. Sci.: Mater. Electron., 2019, 30, 17643-17653. 